Jurnal Ilmu Komunikasi UHO : Jurnal Penelitian Kajian Ilmu Komunikasi dan Informasi.

Volume 6, No. 1, Januari 2021, hlm 19-38

\title{
KERANGKA CUSTOMER INTERFACE PADA WEBSITE ANCOL DALAM MENINGKATKAN CUSTOMER ENGAGEMENT
}

\author{
Pitaloka Ayu Radhinda ${ }^{1}$ Irwansyah $^{2}$ \\ Pascasarjana Ilmu Komunikasi, Fakultas Ilmu Sosial dan Ilmu Politik Universitas Indonesia, \\ Jalan Salemba Raya No. 4, DKI Jakarta, 10430 Indonesia \\ Email : pitaloka.ayu@ui.ac.id
}

\begin{abstract}
ABSTRAK
Keberadaan internet yang sudah menjadi kebiasaan bagi masyarakat ini kemudian melatarbelakangi fenomena peralihan komunikasi face to face menjadi komunikasi yang berlangsung secara digital atau disebut screen to face. Dalam dunia komunikasi pemasaran praktik internet marketing communication menjadi lebih relevan karena kegiatan pemasarannya dilakukan secara sistematis melalui komputer interaktif sehingga dapat menghubungkan para pelanggan online dengan suatu perusahaan melalui perangkat online lainnya. Proses komunikasi screen to face kemudian dijelaskan melalui konsep $8 c$ 's framework of customer interface dan peneliti mengaitkannya dengan peningkatan customer engagement. Penelitian ini dilakukan dengan pendekatan kualitatif dengan metode studi kasus. Hasil penelitian ini menunjukan bahwa media komunikasi yang tampilannya dirancang sesuai dengan pelanggannya dapat membangun rasa keterikatan dan perilaku positif yang akan berdampak pada bisnis yang berjalan.
\end{abstract}

Kata-kata Kunci: internet marketing communication, customer interface, computer mediated communication, customer engagement 
Jurnal Ilmu Komunikasi UHO : Jurnal Penelitian Kajian Ilmu Komunikasi dan Informasi.

Volume 6, No. 1, Januari 2021, hlm 19-38

\title{
CUSTOMER INTERFACE FRAMEWORK ON ANCOL WEBSITE TO INCREASE CUSTOMER ENGAGEMENT
}

\begin{abstract}
The existence of the internet which has become a habit for this society give motivates to the the transition from face-to-face communication to screen-to-face communication. In the world of marketing, practices of internet marketing communication are becoming more relevant. Marketing activities are carried out systematically through interactive computers which make them able to connect online customers to the companies through online tools for instance website. The screen to face communication process then explained through the concept calls $8 c$ 's framework of customer interface and in this research, we try to connect it with customer engagement. This research was conducted with a qualitative approach with a case study method. The results of this study indicate that media of communication that are designed according to their customers can build a sense of engagement and positive behavior that will have an impact on the ongoing business.
\end{abstract}

Keywords: internet marketing communication, customer interface, computer mediated communication, customer engagement 
Jurnal Ilmu Komunikasi UHO : Jurnal Penelitian Kajian Ilmu Komunikasi dan Informasi.

Volume 6, No. 1, Januari 2021, hlm 19-38

\section{PENDAHULUAN}

Perkembangan teknologi saat ini semakin pesat dan meluas pada berbagai ranah industri. Salah satu bentuk perkembangannya adalah penggunaan internet yang sudah tidak dapat lepas dari kehidupan di masyarakat. Internet dapat menghubungkan setiap penggunanya di seluruh dunia yang kemudian mampu membuat semua orang diseluruh dunia dapat saling berkomunikasi satu dengan yang lainnya, baik dengan perangkat pribadi seperti komputer dan juga handphone yang dapat digunakan di kantor, rumah, sekolah, atau dimana saja (Prisgunanto, 2006). Keberadaan internet yang sudah menjadi kebiasaan bagi masyarakat ini kemudian melatarbelakangi fenomena peralihan komunikasi face to face menjadi komunikasi yang berlangsung secara digital atau disebut screen to face (Lee \& Benbasat, 2004). Komunikasi sendiri dipahami sebagai hubungan antara manusia, baik secara individu ataupun grup. Komunikasi menjadi suatu hal yang tidak dapat lepas dari kehidupan manusia.

Barnet Pearce (dalam Littlejohn \& Foss, 2011) menjelaskan bahwa perkembangan komunikasi menjadi sebuah penemuan revolusioner yang disebabkan oleh meningkatnya beraneka ragam teknologi komunikasi. Menurut Kriyantono (2012) kajian ilmu komunikasi bersifat multidisipliner atau lintas bidang yang bersinggungan dengan ilmu sosial lainnya yang mengkaji perilaku manusia. Kajian dari ilmu komunikasi itu sendiri kemudian dapat diaplikasikan pada berbagai macam disiplin ilmu seperti komunikasi massa, komunikasi interpersonal, public relations, komunikasi bisnis yang memiliki objek formal yang sama yaitu produksi, proses, dan pengaruh dari sistem tanda baik verbal maupun non verbal (Kriyantono, 2012). Namun dalam pelaksanaannya ilmu komunikasi berfokus untuk membahas proses transfer pesan atau tanda dengan segala pengaruhnya dalam kehidupan sosial yang mana diketahui bahwa kehidupan sosial terus berubah mengikuti perkembangan teknologi. Salah satu perkembangan multidisipliner dari komunikasi adalah marketing communication yang merupakan perpaduan antara konsep marketing dan komunikasi dimana saat ini praktik marketing communication secara virtual atau melalui media komputer dan jaringan internet disebut sebagai internet marketing communication

Pertama perlu dipahami mengenai marketing communication, yang masing-masing dari marketing dan juga komunikasi memiliki pemahamannya sendiri. Marketing merupakan seperangkat aktivitas yang dilakukan oleh suatu perusahaan atau komunitas untuk menyampaikan nilai-nilai mereka terhadap para pelanggannya (Chitty, 2008). Tidak dapat dilupakan bahwa dalam kegiatan marketing tentu terdapat aktivitas komunikasi yang terjadi. Dan komunikasi dalam konteks ini diartikan sebagai proses yang menyampaikan makna 
Jurnal Ilmu Komunikasi UHO : Jurnal Penelitian Kajian Ilmu Komunikasi dan Informasi.

Volume 6, No. 1, Januari 2021, hlm 19-38

secara bersamaan antar individu ataupun individu dengan organisasi (Chitty, 2008). Menurut Shimp (2003) marketing communication merepresentasikan semua elemen dalam kombinasi brand marketing yang memfasilitasi pertukaran makna dengan membuat suatu makna yang disampaikan kepada pelanggan maupun klien. Dikaitkan dengan perkembangan teknologi saat ini, marketing communication tidak lagi terbatas untuk digunakan pada komunikasi secara face to face, namun juga telah memasuki komunikasi secara screen to face (Mandasari et al., 2014). Dengan demikian konsep internet marketing communication menjadi lebih relevan karena kegiatan pemasarannya dilakukan secara sistematis melalui komputer interaktif sehingga dapat menghubungkan para pelanggan online dengan suatu perusahaan melalui perangkat online lainnya.

Dalam komunikasi yang berjalan secara screen to face ini kemudian dijelaskan lebih lanjut melalui konsep 8c's framework of customer interface yang dikemukakan oleh Rayport \& Jaworski (2001). Konsep ini merupakan komunikasi yang terjalin antara penjual dan pembeli melalui sebuah mediasi berupa teknologi berupa komputer, perangkat WAP, telepon seluler, dan sebagainya (Rayport \& Jaworski, 2001). Customer interface menjadi suatu hal yang pertama kali dilihat oleh para pelanggan perusahaan ketika membuka suatu website perusahaan. Untuk menjalankannya, terdapat 8 elemen yang dikemukakan oleh Rayport \& Jaworski membangun suatu customer interface yang baik bagi perusahaan, yaitu context, content, community, customization, communication, connection, commerce dan collaboration (Kotler \& Keller, 2013; Yang et al., 2008)

Konsep ini menjadi semakin cocok dengan perkembangan digital yang semakin meluas dan ketergantungan manusia terhadap teknologi online. $8 c$ 's framework of customer interface mulai digunakan pada internet marketing communication sebagai dasar strategi dalam berkomunikasi melalui media online yang dilakukan oleh penjual dan pembeli sehingga komunikasi dapat berjalan dengan efektif walaupun komunikasi dilakukan secara online (Hviid \& Jakobsen, 2013). Perusahaan yang memiliki customer interface yang baik dapat mendorong konsumen untuk mengunjungi situs baik untuk pertama kali, kunjungan berulang, hingga terjadinya pembelian (Mandasari et al., 2014). Dari delapan elemen customer interface, terdapat beberapa elemen yang memberikan pengaruh lebih signifikan terhadap minat customer, yaitu context, connection, dan commerce (Radhinda, 2017).

Rayport \& Jaworski (2001) menjelaskan mengenai beberapa elemennya sebagai berikut. Context menjelaskan mengenai bagaimana cara penyampaian maksud dari penggunaan suatu situs. Context sendiri terdiri dari dua hal kunci, yaitu fungsi dan estetika 
Jurnal Ilmu Komunikasi UHO : Jurnal Penelitian Kajian Ilmu Komunikasi dan Informasi.

Volume 6, No. 1, Januari 2021, hlm 19-38

dari suatu website. Secara umum, context berfokus pada presentasi dari suatu website. Beralih kepada elemen connection yang menjelaskan mengenai keterkaitan antara satu situs dengan situs yang lainnya dengan cara menekan suatu link atau tautan yang ditampilkan pada website. Elemen terakhir adalah commerce yang merupakan suatu sistem pendukung agar terciptanya proses transaksi finansial. Hal ini menjadi sangat penting mengingat pada akhirnya yang dituju pada perusahaan online adalah terjadinya transaksi yang dilakukan oleh pelanggan melalui website yang disediakan.

Penelitian yang dilakukan oleh Mandasari, lebih dulu menjelaskan mengenai penggunaan konsep customer interface ini dalam ranah marketing dan penggunaannya dalam menganalisis keputusan konsumen. Dalam penelitian tersebut didapati bahwa 7 aspek dalam kerangka customer interface memberikan pengaruh yang signifikan terhadap keputusan konsumen, namun penelitian tersebut tidak meneliti kaitannya dengan konsep marketing communication dan customer engangement. Hasil uji parsial dalam penelitian Mandasari (2014) mengatakan bahwa "elemen yang berpengaruh secara signifikan terhadap keputusan pembelian adalah content, customization, dan commerce” (Mandasari, 2014). Selanjutnya adalah penelitian yang dilakukan oleh Hviid \& Jakobsen (2013) dengan judul Social Media Strategies yang menjelaskan mengenai penggunaan media sosial Twitter, Facebook, dan Instagram sebagai media komunikasi pemasaran melalui konsep $7 C$ customer interface yang dilakukan secara kualitatif. Berdasarkan penelitian tersebut didapati bahwa pemasaran secara visual lebih disukai dan menarik bagi konsumen namun tidak menjelaskan kaitannya dengan pengguna hingga tahap engangement. Penelitian Hviid \& Jakobsen (2013) menjelaskan bahwa elemen yang memberikan pengaruh secara signifikan dalam marketing communication adalah elemen communication, connection, content, dan context.

Berdasarkan latar belakang dan penelitian terdahulu diatas dapat disimpulkan bahwa elemen dari kerangka customer interface menjadi suatu hal yang penting untuk diperhatikan dalam strategi internet marketing communication bagi perusahaan di berbagai bidang industri. Penelitian ini menggunakan Taman Impian Jaya Ancol sebagai objek penelitian. Taman Impian Jaya Ancol atau lebih dikenal dengan sebutan Ancol merupakan salah satu rekreasi yang dikelola oleh Pemerintah Provinsi DKI Jakarta. Dari data yang dipaparkan dalam Dinas Pariwisata dan Kebudayaan (dalam Portal Statistik Sektoral Provinsi DKI Jakarta, 2019), Ancol merupakan tujuan utama bagi para wisatawan saat liburan. Selain itu dari data internal perusahaan yang dipaparkan oleh Rika selaku corporate communication manager di PT Taman Impian Jaya Ancol, pengunjung Ancol mencapai 18 juta pengunjung 
Jurnal Ilmu Komunikasi UHO : Jurnal Penelitian Kajian Ilmu Komunikasi dan Informasi.

Volume 6, No. 1, Januari 2021, hlm 19-38

pada tahun 2019 silam. Dengan tingginya pengunjung Ancol, maka semakin dibutuhkan suatu teknologi yang dapat memfasilitasi masyarakat agar dapat tetap terhubung dengan Ancol. Keterkaitan masyarakat dengan Ancol kemudian diharapkan dapat mempertahankan eksistensi dan perhatian masyarakat atas keberadaan Ancol. Salah satu teknologi yang saat ini digunakan oleh Ancol adalah website sebagai bentuk internet marketing communication yang digunakan.

Berkaitan dengan bentuk internet marketing communication dan keberadaan customer interface pada suatu website bisa menjadi tidak ada nilainya apabila tidak adanya keterkaitan pelanggan atau customer engagement dengan perusahaan penyedia. Customer engagement didefinisikan oleh Marketing Science Institute sebagai manifestasi perilaku pelanggan terhadap merek atau perusahaan di luar aktivitas pembelian yang dihasilkan dari motivasi individu pelanggan seperti rekomendasi, WoM, interaksi antar konsumen, penulisan ulasan, dan aktivitas lainnya yang sejenis (Institute, n.d.). Dan website sebagai media komunikasinya dapat menyediakan berbagai informasi teks, gambar, audio, maupun video agar dapat tetap terhubung satu dengan yang lainnya antara perusahaan dengan konsumen. Dengan adanya customer engagement program yang dilakukan dapat menimbulkan sebuah sharing society, yang merupakan masyarakat dapat saling memberi dan meneruskan informasi menjadi lebih luas. Pelanggan saling membagikan dan meneruskan hal-hal yang mereka anggap penting dan menarik kepada orang-orang disekitar mereka.

Pertumbuhan internet dan aktivitas digital ini menjadikan interaksi antara pelanggan dengan pelanggan dan pelanggan dengan perusahaan menjadi lebih mudah untuk dilakukan (Evans, 2010; Verhoef et al., 2010). Hal tersebut menjadi dasar bagi Taman Impian Jaya Ancol mulai beralih menggunakan media online sebagai sarana pemasaran yang dilakukan. Berdasarkan hal tersebut maka penelitian ini akan membahas lebih lanjut mengenai Customer Interface sebagai bentuk Internet Marketing Communication dalam meningkatkan Customer Engagement. Penelitian ini juga akan membahas mengenai komunikasi termediasi komputer (CMC) dalam konteks website customer interface. Pemilihan ini didasari pada adanya komunikasi atau kegiatan sharing konten yang akan dilakukan oleh customer akan suatu situs kepada orang-orang disekitarnya. Konten yang dibagikan oleh customer tentu merupakan konten yang terdapat dalam website Ancol. Hasil kajian ini kemudian diharapkan dapat menjadi referensi akademis dalam mengamati fenomena penggunaan customer interface dalam meningkatkan customer engagement. Kebaruan dalam penelitian ini bersandar pada penggunaan suatu teknologi baru dalam komunikasi termediasi dan bagaimana suatu 
Jurnal Ilmu Komunikasi UHO : Jurnal Penelitian Kajian Ilmu Komunikasi dan Informasi.

Volume 6, No. 1, Januari 2021, hlm 19-38

tampilan media pemasaran memberikan dampak pada keterikatan hubungan antar individu dan perusahaan.

Pada latar belakang telah dijelaskan mengenai konsep website customer interface dan komunikasi pemasaran yang kemudian dikaitkan dengan konsep integrated marketing communication, maka berdasarkan hal tersebut rumusan penelitian ini adalah bagaimana konsep internet marketing communication yang diterapkan melalui customer interface framework pada website Taman Impian Jaya Ancol dapat meningkatkan customer engagement?

Berdasarkan pemaparan latar belakang dan rumusan masalah diatas, maka tujuan penulisan penelitian ini adalah untuk menjelaskan mengenai fenomena ketertarikan konsumen dan customer engangement pada website Taman Impian Jaya melalui customer interface dan kaitannya dengan konsep internet marketing communication. Selain itu penelitian ini diharapkan dapat memberikan manfaat teoritis untuk memperluas konsep customer interface dalam konteks penggunaannya di salah satu Taman Rekreasi di Indonesia dan dapat menjadi analisis dasar untuk menciptakan customer interface yang efektif, khususnya dalam dunia komunikasi pemasaran.

Penelitian ini menggunakan konsep internet marketing communication sebagai dasar pemikiran yang kemudian difokuskan pada website. Penggunaan website sebagai sarana marketing dan komunikasi perlu dirancang sedemikian rupa agar dapat menyampaikan pesan dan informasi yang sesuai dengan tujuan awal. Penelitian ini kemudian memperhatikan pembentukan pesan dalam website dengan menggunakan konsep 8C's Framework of Customer Interface, yaitu Context, Content, Community, Costumization, Communication, Connection, Commerce, Collaboration yang dikemukakan oleh Rayport \& Jaworski (2001) dan Yang dkk (2008). Analisa penggunaan 8C's Framework of Customer Interface pada website Ancol sebagai medium dalam dilakukannya internet marketing communication selanjutnya akan dikaitkan dengan dampaknya pada customer engangement. 
Jurnal Ilmu Komunikasi UHO : Jurnal Penelitian Kajian Ilmu Komunikasi dan Informasi.

Volume 6, No. 1, Januari 2021, hlm 19-38

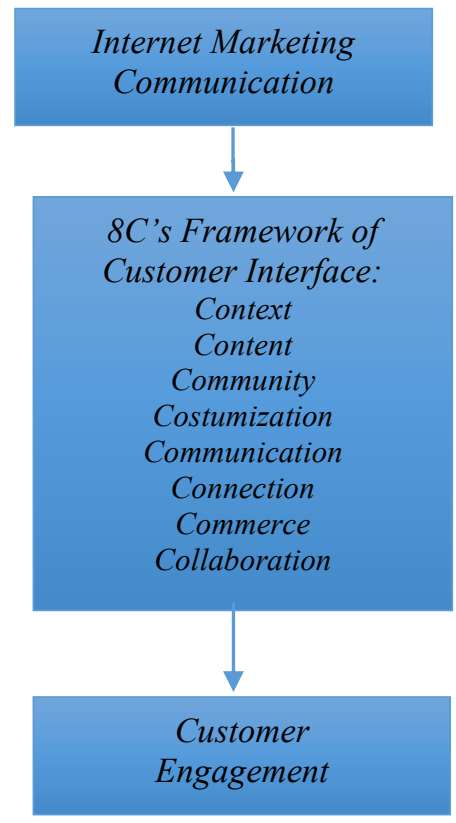

Gambar 1. Kerangka Penelitian

Sumber: (Ballantyne \& Varey, 2006; Rayport \& Jaworski, 2001; Yang et al., 2008, Cook, 2010)

\section{METODE PENELITIAN}

Penelitian ini dimulai dengan suatu teori atau konsep, namun tidak bermaksud untuk menguji hipotesis. Karena hal tersebut peneliti menggunakan paradigma post-positivisme dan pendekatan yang digunakan adalah pendekatan kualitatif. Pendekatan ini dilakukan dengan tujuan memahami suatu fenomena mengenai apa yang dialami oleh subjek penelitian seperti persepsi, motivasi, perilaku, tindakan dan lain-lain secara menyeluruh dan dengan cara mendeskripsikan dalam bentuk kata-kata dan bahasa yang disesuaikan pada suatu konteks khusus dengan memanfaatkan berbagai metode ilmiah (Moleong, 2017). Penelitian kualitatif juga mengkaji kualitas hubungan, kegiatan, situasi, atau material dengan penekanan kuat pada deskripsi menyeluruh dalam menggambarkan rincian segala sesuai yang terjadi pada suatu kegiatan atau situasi (Mukhtar, 2013).

Strategi penelitian yang digunakan dalam penelitian ini adalah studi kasus dimana penelitian akan dilakukan dengan cara mengamati bentuk marketing communication yang terjadi pada website melalui konsep framework of customer interface. Penelitian ini menempatkan sesuatu atau objek yang diteliti sebagai sebuah kasus. Melalui studi kasus peneliti dimungkinkan untuk memahami subjek secara mendalam dan memandang subjek sebagaimana subjek penelitian memahami dan mengenal dunianya sendiri. Selain itu 
Jurnal Ilmu Komunikasi UHO : Jurnal Penelitian Kajian Ilmu Komunikasi dan Informasi.

Volume 6, No. 1, Januari 2021, hlm 19-38

penggunaan studi kasus bertujuan meningkatkan pengetahuan tentang peristiwa yang nyata dengan konteksnya. Studi kasus yang digunakan dalam penelitian ini adalah studi kasus deskriptif dimana kasus diteliti untuk memberikan gambaran mendalam atau detail terhadap studi kasus tersebut (Robert, 2012).

Dalam penelitian ini menggunakan satu kasus dengan dua objek yaitu customer interface dan customer interface pada Website Taman Impian Jaya Ancol dan objek yang diteliti adalah Divisi Digital dan Divisi Brand Development dari Taman Impian Jaya Ancol. Masing-masing VP dari Divisi tersebut kemudian akan menjadi informan dalam penelitian ini. Berdasarkan hal tersebut tipe studi kasus yang digunakan adalah single case embedded. Tipe ini menurut Robert (2012) dapat digunakan apabila terdapat satu kasus dan terdapat unit multi analisis.

Teknik pengumpulan data yang dilakukan dalam penelitian ini adalah dengan menggunakan data primer berupa wawancara virtual dan data sekunder yang berupa observasi. Peneliti akan melakukan wawancara dengan dua orang informan yang berperan dalam pembentukan website Ancol dan pelanggan yang aktif/pernah menggunakan website Ancol. Wawancara dalam penelitian ini dilakukan secara virtual yaitu dengan video conference karena peneliti berupaya mendapatkan informasi seakurat wawancara secara langsung. Secara umum wawancara melalui video conference dilakukan tidak jauh berbeda dengan wawancara langsung yang terjadi diruang dan waktu yang sama, namun dalam wawancara video conference informan dan peneliti bertemu pada saat berada di lokasi yang berbeda (Nehls et al., 2014). Wawancara yang dilakukan dengan video conference dapat memperluas batasan, mendeskripsikan penelitian dengan baik, dan dilakukan dengan cara yang nyaman dan mudah diakses (Nehls et al., 2014). Aplikasi yang digunakan untuk video conference merupakan Google Meet. Dalam melakukan wawancara melalui video conference perlu diperhatikan mengenai logistik yang digunakan, perekrutan informan, hubungan yang baik dengan informan, persiapan wawancara, rekaman video wawancara dan analisisnya (Nehls et al., 2014). Dan observasi yang dilakukan pada penelitian ini adalah observasi non partisipan dimana peneliti tidak terlibat secara langsung dan hanya sebagai pengamat independen. Pengamatan dilakukan melalui situs website dan media sosial yang yang menunjukkan customer interface dan customer engagement yang terjadi secara digital.

Selanjutnya untuk analisis data peneliti menggunakan coding sebagai langkah pertama dalam mengembangkan kategori, pola dan konsep penelitian. Coding digunakan untuk memudahkan peneliti dalam mengatur banyaknya kata dalam hasil wawancara dan 
Jurnal Ilmu Komunikasi UHO : Jurnal Penelitian Kajian Ilmu Komunikasi dan Informasi.

Volume 6, No. 1, Januari 2021, hlm 19-38

membantu untuk menafsirkan fenomena internet marketing communication yang terjadi. Dalam melakukan coding peneliti memerlukan dokumen tertulis/rekaman seperti transkrip wawancara atau gambaran pengamatan secara terperinci (Daymon \& Holloway, 2010). Konfirmasi data atau keabsahan data dalam penelitian ini akan dilakukan melalui triangulasi data yang merupakan teknik pemeriksaan data dengan memanfaatkan suatu hal selain data yang digunakan sebagai pembanding data tersebut. Triangulasi dilakukan oleh peneliti terhadap informan, data dokumentasi, dan diskusi dengan berbagai teori (Mukhtar, 2013)

\section{HASIL DAN PEMBAHASAN}

Pada bagian ini, peneliti akan memaparkan hubungan konsep yang telah dijelaskan pada subbab sebelumnya dengan fenomena yang terjadi di website Taman Impian Jaya Ancol Analisa Website sebagai sarana Internet Marketing Communication Taman Impian Jaya Ancol

Penggunaan website dipilih oleh Ancol sebagai salah satu sarana atau media komunikasi dan promosi yang ditujukan kepada masyarakat dengan tujuan menciptakan hubungan yang baik antara Ancol dan masyarakat. Hal ini sesuai dengan penjelasan bahwa hasil akhir kegiatan internet marketing communication adalah adanya hubungan komunikasi yang baik antara perusahaan dengan khalayak (Ballantyne \& Varey, 2006). Website menjadi sarana yang digunakan untuk memberikan informasi yang lebih detail dan lengkap dibandingkan dengan media sosial lainnya sehingga masyarakat dapat melakukan satu kali pemberhentian untuk mendapatkan berbagai informasi hingga aktivitas pembelian.

Dari data yang dimiliki oleh divisi digital Ancol (2019), pendapatan diraih sebanyak $10 \%$ melalui penjualan secara online dan peringkat pertama penjualan berlangsung di website Ancol. Hal ini membuktikan bahwa komunikasi dan promosi yang dilakukan melalui website memberikan dampak perkembangan yang baik bagi perusahaan. Selain itu dari hasil wawancara dengan informan yang merupakan tim digital Ancol, diketahui bahwa tujuan utama pembentukan website Ancol adalah untuk tujuan promosi dan penjualan. Data yang dimiliki oleh tim Digital Ancol juga mengatakan bahwa sebagian besar pengunjung website Ancol juga akan datang ke website sebelum pembelian tiket untuk mencari informasi promo dan melakukan pembelian di website.

Website menjadi salah satu media yang dipilih oleh pengunjung Ancol dalam mencari informasi dan melakukan pembelian, hal ini diperkuat dengan pernyataan informan yang aktif menggunakan website Ancol. Narasumber 2 mengatakan bahwa ia akan mendatangi website 
Jurnal Ilmu Komunikasi UHO : Jurnal Penelitian Kajian Ilmu Komunikasi dan Informasi.

Volume 6, No. 1, Januari 2021, hlm 19-38

Ancol terlebih dahulu sebelum ia datang ke Ancol untuk berekreasi. Ia akan mencari informasi seperti promo tiket dan acara special apa yang sedang berlangsung di Ancol. Dalam aktivitas tersebut, terjadi proses komunikasi secara screen to face yang terjadi antara pelanggan dengan perusahaan. Dengan adanya internet yang dapat digunakan dalam proses marketing komunikasi, penting juga untuk menggunakan berbagai media yang terkoneksi dengan internet agar pesan yang disampaikan dapat diterima secara maksimal. Narasumber 2, sebagai informan penelitian ini mengatakan bahwa media komunikasi pemasaran yang penting untuk digunakan saat ini selain website adalah aplikasi, media sosial seperti Instagram, youtube, juga bekerjasama dengan para influencer. Saat ini, Ancol menggunakan www.ancol.com sebagai alamat websitenya dan akun instagram @ancoltamanimpian. Nama Ancol Taman Impian ini juga digunakan sebagai nama dari akun youtube yang dimiliki oleh Ancol. Dari hal tersebut terlihat bahwa konten marketing yang disampaikan melalui internet dapat lebih menarik dan interaktif dimata pelanggan. Hal ini sesuai dengan penjelasan (Shimp, 2004) bahwa internet diyakini sebagai media yang jauh lebih interaktif daripada media lainnya.

Informan tim digital Ancol menyampaikan bahwa dalam satu kali kunjungan ke website, rata-rata waktu yang dihabiskan pada halaman website adalah 2 menit 30 detik. Perilaku tersebut sesuai dengan yang dikemukakan oleh Shimp (2007) bahwa waktu yang umumnya dihabiskan oleh para pengguna internet untuk fokus pada suatu pesan adalah 1 menit hingga 15 menit. Karenanya proses internet marketing communication dari sisi The offer (expression) dan The offer (expression) (Ballantyne \& Varey, 2006) sudah dikemas dengan baik. Selain itu berdasarkan wawancara yang dilakukan dengan kedua narasumber, didapati adanya keselarasan antara tujuan perusahaan dan apa yang didapatkan oleh pelanggan. Dari hal tersebut dapat terlihat bawa adanya hubungan komunikasi yang baik antara perusahaan dengan khalayak yang berjalan melalui internet atau secara screen to face. Komunikasi berjalan secara efektif dengan menggunakan internet dan website sebagai medianya. Hal ini dibuktikan dengan sampainya pesan utama dalam website yaitu untuk menyampaikan promosi dan memberikan pengalaman yang baik terhadap para pelanggannya saat akan berkunjung ke Ancol. Berikut adalah kutipan jawaban wawancara dengan Narasumber 2 saat ditanya mengenai tujuan mendatangi website.

" Promo+ tempat pembelian tiket (karena emang tujuannya beli tiket). Kayak Dufan suka ada promo pembelian tiket dengan bundle yang jatuhnya lebih murah. nah kan itu biasanya ada syaratnya lumayan menghemat lah. 
Jurnal Ilmu Komunikasi UHO : Jurnal Penelitian Kajian Ilmu Komunikasi dan Informasi.

Volume 6, No. 1, Januari 2021, hlm 19-38

Hasil wawancara ini ini menunjukan bahwa narasumber cenderung sudah mengetahui bahwa apabila dirinya mencari informasi mengenai promo dan akan melakukan pembelian, ia akan datang ke website Ancol.

\section{Aplikasi 8C's Framework of Customer Interface pada Website Taman Impian Jaya} Ancol

Berjalannya suatu komunikasi secara screen to face tidak lepas dari konsep computer mediated communication yang mengharuskan pesan yang dibuat memiliki kompleksitas yang rendah, tidak ambigu, dan dapat mempengaruhi emosi penerima pesan, dalam hal ini dapat diperhatikan budaya komunikasinya (Morreale et al., 2007). Karenanya untuk mencapai komunikasi yang baik pembuatan website dirancang dengan beberapa kerangka atau framework yaitu context, content, community, customization, communication, connection, commerce, dan collaboration (Rayport \& Jaworski, 2001; Yang et al., 2008). Pertama akan dibahas mengenai context. Berdasarkan wawancara yang dilakukan dengan narasumber 1 merujuk pada penjelasan Rayport \& Jaworski (2001) bahwa dalam aspek context pesan disampaikan secara estetika dan juga fungsional. Konteks dibangun secara estetika dengan menggunakan warna dan font yang disesuaikan dengan identitas perusahaan. Secara fungsional informasi mengenai produk yang ditawarkan disampaikan secara detail dan menyeluruh sehingga pelanggan dapat memahami apa yang ingin disampaikan oleh perusahaan secara tertulis. Penjelasan tersebut kemudian selaras dengan penjelasan narasumber 2 yang secara aktif menggunakan website Ancol sebelum berkunjung ke Taman Impian Jaya Ancol. Ia mengatakan bahwa dirinya merasakan keberadaan Ancol saat membuka website ancol.com, hal itu dikarenakan pemilihan warna dan font dalam website sudah merepresentasikan Ancol sebagai tempat rekreasi yang bersifat fun dan tidak kaku.

Poin kedua adalah content dalam website Ancol, dikonfirmasi dari narasumber 1 bahwa tujuan utama pembuatan website adalah untuk media komunikasi mengenai penjualan dan juga promosi produk perusahaan, hal ini sesuai dengan penjelasan Rayport \& Jaworski (2001) mengenai dimensi content yang berupa appeal mix. Narasumber 1 juga mengatakan bahwa dalam menyampaikan konten tersebut ia menggunakan gambar sebagai pendukung teks atau disebut sebagai multimedia mix (Rayport \& Jaworski, 2001). Penggunaan multimedia mix kemudian membantu narasumber 2 untuk lebih memahami dan mendapatkan inti dari pesan yang disampaikan. Karenanya diketahui bahwa adanya pesan teks yang didukung dengan pesan visual dapat membantu pesan diterima lebih efektif oleh komunikan. 
Jurnal Ilmu Komunikasi UHO : Jurnal Penelitian Kajian Ilmu Komunikasi dan Informasi.

Volume 6, No. 1, Januari 2021, hlm 19-38

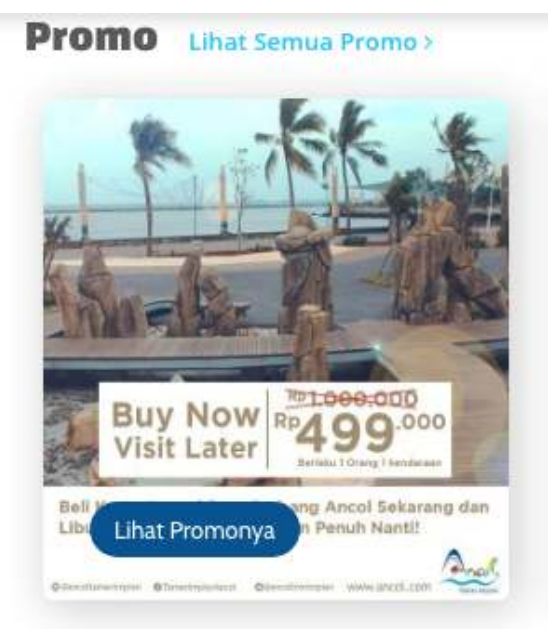

Gambar 2. Multimedia Mix dalam Website Ancol

Sumber: ancol.com

Poin ketiga adalah community. Pada poin ini narasumber 1 menjelaskan untuk saat ini sebuat fitur seperti forum diskusi para pelangan masih belum ada dan belum menjadi prioritas, namun ia setuju bahwa fitur komunitas menjadi hal yang penting bagi pelanggan untuk saling berkomunikasi tanpa ada intervensi perusahaan dan dapat bertukar pengalaman. Hal ini merujuk juga pada pemahaman narasumber yang mengatakan bahwa saat memasuki website diharapkan para pelanggan bisa merasakan suatu "experience" yang memberikan kesan "wah". Namun hal ini cukup berbeda dari penjelasan narasumber 2 yang mengatakan fitur komunitas tidak bergitu penting karena informasi tersebut bisa didapatkan dari media sosial lain dan cenderung akan memenuhi website jika pesan yang disampaikan oleh pengunjung lain tidak akurat. Dengan demikian, tidak adanya fitur komunitas maka tidak ada pertukaran pesan secara langsung dan berkelanjutan bagi para pengguna situs. Ini merupakan bentuk non interactive communication dari aspek community.

Poin selanjutnya adalah customization. Komunikasi yang efektif secara online dapat berjalan dengan baik apabila sesuai dengan preferensi pelanggan (Hviid \& Jakobsen, 2013). Berdasarkan Rayport \& Jaworski (2001) terdapat dua jenis customization, yaitu tailoring dan personalization. Tailoring menurut Rayport \& Jaworski (2001) merupakan suatu kondisi dimana situs dapat dirancang berdasarkan perilaku dan respon konsumen sebelumnya atau berdasarkan rekomendasi dari para penggunanya, sedangkan personalization merupakan kustomisasi dilakukan oleh pengguna (Rayport \& Jaworski, 2001). Dari hasil wawancara dengan kedua 
Jurnal Ilmu Komunikasi UHO : Jurnal Penelitian Kajian Ilmu Komunikasi dan Informasi.

Volume 6, No. 1, Januari 2021, hlm 19-38

narasumber didapati bahwa kustomisasi pada website Ancol tidak berjalan secara personalization namun dijalankan berdasarkan tailoring. Website tidak diatur sesuai personalisasi pelanggan namun tampilan website disesuaikan dengan respon konsumen pada tampilan sebelumnya (Rayport \& Jaworski, 2001). Narasumber 1 menjelaskan bahwa untuk mencapai komunikasi yang efektif bagi para pelanggannya, maka dilakukan penyesuaian tampilan dengan memprioritaskan tampilan mobile website daripada tampilan computer website. Hal ini karena 90\% pengunjung Ancol membuka website melalui handphone.

Pada poin communication, terdapat dimensi interactive yang merupakan bentuk komunikasi yang berjalan secara dua arah antara perusahaan dan pengguna (Rayport \& Jaworski, 2001). Dijelaskan pula bahwa komunikasi yang berjalan dua arah dalam media komunikasi online dapat membantu komunikasi berjalan lebih efektif, terlebih dalam promosi dan penjualan (Hviid \& Jakobsen, 2013). Dari wawancara yang telah dilakukan dengan kedua narasumber, didapati bahwa komunikasi yang berjalan di website Ancol antara perusahaan dan pelanggan berjalan interaktif. Hal ini disampaikan oleh narasumber 2 yang menyatakan bahwa terdapat fitur live chat yang dapat digunakan secara langsung untuk mendapat bantuan saat menggunakan website. Fitur live chat ini pun berperan sebagai asisten online bagi para pelanggan untuk mencapai informasi yang mereka cari.

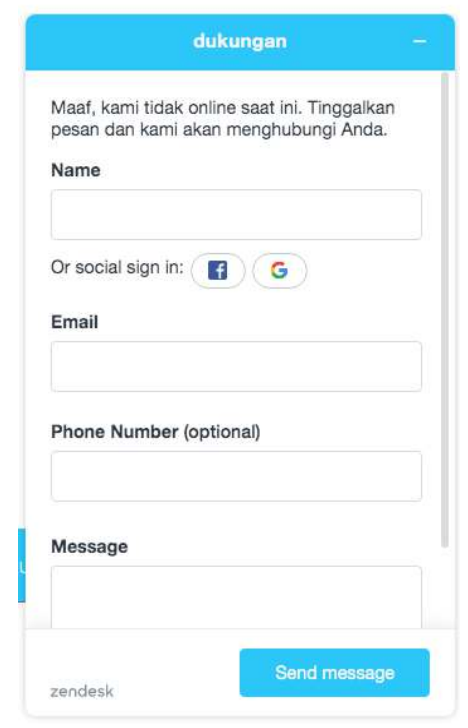

Gambar 3. Fasilitas interactive communication dalam Website

Sumber: ancol.com

Poin ke enam adalah connection yang berkaitan dengan terhubungnya situs website dengan situs lainnya (Rayport \& Jaworski, 2001). Dari hasil wawancara dengan narasumber 
Jurnal Ilmu Komunikasi UHO : Jurnal Penelitian Kajian Ilmu Komunikasi dan Informasi.

Volume 6, No. 1, Januari 2021, hlm 19-38

1, peneliti menyimpulkan bahwa pada website Ancol digunakan connection dengan jenis pathway connection dimana pengguna dapat terhubung dengan link situs yang tersedia pada halaman situs tanpa meninggalkan situs semula. Kedua narasumber mengkonfirmasi bahwa tersedianya shortcut link yang menghubungkan website dengan website lainnya tanpa menutup website utama. Contoh shortcut yang tersedia adalah website corporate, Instagram @ancoltamanimpian, twitter, youtube dan facebook. Aspek connection ini disiapkan untuk memudahkan para pelanggan dalam mendapatkan informasi diluar website utama.

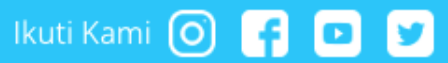

Gambar 4. Konektivitas melalui logo-logo

Sumber: ancol.com

Poin selanjutnya adalah commerce yang merupakan salah satu aspek yang paling diperhatikan dalam website Ancol. Pengaturan tampilan serta pemilihan kata diatur dan disesuaikan dengan beberapa promosi yang sedang berjalan di unit rekreasi Ancol. Hal ini ditujukan agar pesan yang diberikan tidak memberikan makna yang ambigu kepada para pelanggan. Hal ini disampaikan oleh narasumber 1 bahwa pada bagian pembelian tiket wahana dijelaskan promo seperti bundling atau potongan harga tertentu agar pelanggan dapat memilih tiket promo sesuai dengan keinginan dan kebutuhannya. Selain itu, dalam proses pembelian pelanggan melakukan registrasi secara sederhana yaitu dengan mengisi email, nama, dan nomor telepon tanpa melakukan sign ini. Ini menjadikan pelanggan lebih mudah dalam bertransaksi yang kemudian di konfirmasi oleh narasumber 2. Dari penjelasan narasumber 1 diketahui bahwa proses pembayaran dapat dilakukan dengan beberapa cara sehingga memudahkan pelanggan untuk memilih yang sesuai. Selain itu mengenai keamanan telah dijamin karena Ancol telah bekerjasama dengan pihak ketiga dan disampaikan kepada para pelanggan dengan memasang logo pihak ketiga di halaman pembayaran. Dari proses ini dapat disimpulkan bahwa apabila produk, proses, hingga keamanan dikomunikasikan kepada pelanggan dengan baik maka akan menimbulkan perilaku pembelian.

Poin terakhir adalah collaboration. Dari hasil wawancara dengan kedua narasumber didapati bahwa dimensi collaboration yang terdapat dalam website Ancol adalah saran dan komentar yang merupakan kemampuan situs memungkinkan konsumen untuk memberikan saran dan komentar yang bertujuan untuk pengembangan produk (Hansen \& Bjørn-Andersen, 
Jurnal Ilmu Komunikasi UHO : Jurnal Penelitian Kajian Ilmu Komunikasi dan Informasi.

Volume 6, No. 1, Januari 2021, hlm 19-38

2013). Narasumber 2 mengatakan bahwa saran dan komentar menjadi suatu wadah yang penting untuk perkembangan website perusahaan dan sebagai sarana komunikasi tidak langsung bagi pelanggan. Hal tersebut didukung oleh narasumber 1 bahwa saran dan komentar menjadi sarana awal dari kolaborasi yang dapat terbentuk antara pelanggan dan perusahaan. Dari hal ini terlihat adanya keselarasan antara tujuan perusahaan dengan sikap dari para pelanggannya. Fitur saran dan komentar ini kemudian menjadi media komunikasi bagi kedua pihak untuk menjalankan suatu kolaborasi.

\section{Peran Customer Interface Website Taman Impian Jaya Ancol pada Customer Engagement}

Customer interface berusaha membuat website menjadi lebih komunikatif sehingga pesan yang disampaikan dapat diterima dengan baik oleh para pelanggan hingga menimbulkan rasa keterikatan bagi seluruh pelanggan. Dengan kata lain customer interface berjalan dengan didasari oleh $\mathrm{CMC}$ yang melibatkan pertukaran informasi baik dalam bentuk teks, audio atau video yang ditransmisikan dan dikendalikan oleh penggunaan komputer teknologi komunikasi (Bubaš, 2001). Komunikasi yang berjalan termediasi dengan komputer (CMC)) dapat dipengaruhi oleh motivasi seseorang dalam mencapai suatu tujuan, pengetahuan teknis dan kemampuan membuat konten digital dan kemampuan pemilihan media komunikasi (formal atau informal) (Morreale et al., 2007). Dari hasil wawancara dengan narasumber 2 diketahui bahwa sebelum memasuki website Ancol, ia sudah memiliki tujuan mengenai apa yang akan dicari dan ia memiliki kemampuan untuk menemukan website Ancol melalui mesin pencari Google.

Dari penjabaran mengenai customer interface dan aplikasinya terhadap pelanggan pada sub bab sebelumnya, didapati bahwa adanya keterkaitan pelanggan atau customer engagement yang terdiri dari cognitive attachment, attitudinal attachment, dan behavioral attachment (Cook, 2010). Dari penjelasan narasumber 2, keterikatan secara kognitif terlihat dari diterimanya informasi yang diberikan melalui website oleh narasumber 2. Setelah diterimanya informasi muncul persepsi dari narasumber 2 mengenai tempat-tempat yang akan didatangi saat berkunjung ke Ancol akan membuat dirinya merasa senang. Selain itu, penerimaan pesan di website juga menumbuhkan kembali memori narasumber 2 mengenai keadaan Ancol pada saat dulu. Dari hal tersebut terlihat bahwa adanya keterikatan secara kognitif dari customer interface website Ancol kepada kognitif para pelanggannya.

Dimensi selanjutnya adalah attitudinal attachment yang merupakan tahap afeksi positif seperti menceritakan hal atau pengalaman baru, keterlibatan sosial maupun 
Jurnal Ilmu Komunikasi UHO : Jurnal Penelitian Kajian Ilmu Komunikasi dan Informasi.

Volume 6, No. 1, Januari 2021, hlm 19-38

interpersonal (Cook, 2010). Dari wawancara yang dilakukan dengan narasumber 2 didapati bahwa narasumber memiliki perasaan yang positif dengan website Ancol karena mendapatkan kemudahan dan juga efektivitas waktu dalam membeli tiket. Selain itu narasumber 1 juga mengatakan bahwa banyaknya respon positif yang didapatkan Ancol mengenai proses informasi serta pembelian tiket yang dapat dilakukan melalui website Ancol, terlebih respon positif tersebut dibagikan oleh para pelanggan melalui media sosial yang berarti mereka telah membagikan pengalaman positif mereka kepada khalayak lainnya secara sukarela.

Pada attitudinal attachment ini, narasumber 2 mengatakan bahwa saat dirinya memasuki website Ancol ia merasakan perasaan antusias karena ambience website sudah menunjukan karakteristik Ancol. Antusias untuk mendatangi Ancol semakin meningkat terlebih saat sudah dilakukannya pembelian tiket. Selanjutnya narasumber 2 juga mengatakan bahwa saat ia berseluncur mencari informasi di website Ancol ia merasa nyaman dan menikmati apa yang disediakan. Ia mendapatkan informasi yang dibutuhkan hingga menimbulkan kepuasan dan kesenangan dalam dirinya setelah membuka website Ancol. Hal ini menunjukan bahwa customer interface website Ancol menimbulkan customer engagement sebagaimana dijelaskan (Dessart et al., 2015) bahwa enjoyment dan enthusiasm merupakan bentuk dari customer engagement.

Tingkatan terakhir dari customer engagement adalah behavioral attachment dimana adanya suatu usaha yang dilakukan untuk dapat membangun hubungan yang kuat antara pelanggan dan brand dengan menyatukan keduanya ke dalam komunikasi yang berjalan dua arah (Cook, 2010). Hasil wawancara dengan narasumber 2 peneliti mengetahui bahwa keterikatan pada pelanggan juga mencapai tahap perilaku kebiasaan yaitu dengan dilakukannya rekomendasi kepada individu lainnya untuk mendatangi website Ancol dalam mencari informasi yang detail dan akurat. Selain itu saat dilakukannya wawancara, narasumber 2 menyampaikan beberapa masukan untuk website Ancol secara sukarela tanpa adanya pertanyaan langsung yang menunjukan adanya perilaku yang mencoba untuk membangun hubungan melalui konten yang disediakan pada website, seperti masukan mengenai jingle Dufan yang bisa dipasang di website Ancol untuk menggali kembali memori akan wahana rekreasi di Ancol. Komunikasi yang berjalan demikian menunjukan bahwa website Ancol dapat memberikan informasi dan proses komunikasi yang efektif hingga adanya customer engagement yang terbangun antara perusahaan dan pelanggan. 
Jurnal Ilmu Komunikasi UHO : Jurnal Penelitian Kajian Ilmu Komunikasi dan Informasi.

Volume 6, No. 1, Januari 2021, hlm 19-38

\section{SIMPULAN}

Hasil penelitian yang dilakukan menunjukan bahwa konsep internet marketing communication dilakukan oleh Ancol dengan media berupa website Ancol.com. Adapun pembuatan desain website tersebut mengacu kepada 8 kerangka customer interface yang dikemukakan oleh Rayport \& Jaworski (2001), namun pada pengaplikasiannya kerangka ini kemudian disesuaikan dengan karakteristik perusahaan dan juga kebiasaan pengguna atau pelanggan website Ancol.com. Hal ini dilakukan agar penyampaian pesan komunikasi dapat berjalan dengan efektif dan memberikan hasil yang diinginkan yaitu meningkatnya penjualan melalui website Ancol.com. Dari penelitian ini didapati bahwa melalui media komunikasi yang tampilannya dirancang sesuai dengan pelanggannya dapat membangun rasa keterikatan dan perilaku positif yang akan berdampak pada bisnis yang berjalan. Ketertarikan pelanggan terhadap suatu produk ini kemudian dapat dikembangkan dan dijaga dengan baik dengan meningkatkan pengalaman baik yang akan diterima oleh pelanggan selama menggunakan media komunikasi online. Konsep penggunaan tampilan kemudian juga dapat digunakan sebagai wajah utama dari sebuah perusahaan dalam dunia maya atau online. Penelitian selanjutnya dapat menggunakan konsep customer interface untuk digunakan pada media sosial lainnya seperti instagram ataupun facebook dengan industri yang berbeda dan dikaitkan dengan dimensi lainnya dari customer engagement. 
Jurnal Ilmu Komunikasi UHO : Jurnal Penelitian Kajian Ilmu Komunikasi dan Informasi.

Volume 6, No. 1, Januari 2021, hlm 19-38

\section{DAFTAR PUSTAKA}

Ballantyne, D., \& Varey, R. J. (2006). Creating value-in-use through marketing interaction: The exchange logic of relating, communicating and knowing. Marketing Theory, 6(3), 335-348. https://doi.org/10.1177/1470593106066795

Bubaš, G. (2001). Computer mediated communication theories and phenomena: Factors that influence collaboration over the internet. 3rd CARNet Users Conference, Zagreb, Hungary, Cmc.

http://citeseerx.ist.psu.edu/viewdoc/download?doi=10.1.1.111.822\&rep=rep1\&type=pdf

Chitty. W, et all. (2008). Integrated Marketing Communications. Cengage Learning.

Cook, S. (2010). Customer Care Excellent: How to Create Effective Customer Focus. Kogan Page.

Daymon, C., \& Holloway, I. (2010). Qualitative research methods in public relations and marketing communications: Second edition. In Qualitative Research Methods in Public Relations and Marketing Communications: Second Edition. https://doi.org/10.4324/9780203846544

Dessart, L., Veloutsou, C., \& Morgan-Thomas, A. (2015). Consumer engagement in online brand communities: A social media perspective. Journal of Product and Brand Management. https://doi.org/10.1108/JPBM-06-2014-0635

Evans, D. (2010). Social Media Marketing: The Next Generation of Business Engagement. Wiley Publishing.

Hansen, R., \& Bjørn-Andersen, N. (2013). Cube assessment framework for B2C websites applied in a longitudinal study in the luxury fashion industry. Journal of Theoretical and Applied Electronic Commerce Research, 8(2), 1-20. https://doi.org/10.4067/S071818762013000200002

Hviid, M., \& Jakobsen, B. (2013). Social media strategies (A study of social media strategies on Facebook, Instagram, and Twitter exemplified through the fashion industry). Aarhus University.

Institute, M. S. (n.d.). Understanding Customer Experience and Behaviour. In 2012 (2010th2012th ed.). Research Priorities.

Kotler, P., \& Keller, K. L. (2013). Marketing Management 14e. Pearson Education Limited. In Pearson. https://doi.org/10.1080/08911760903022556

Kriyantono, R. (2012). Etika filsafat ilmu komunikasi. UB Press.

Lee, Y. E., \& Benbasat, I. (2004). A framework for the study of customer interface design for mobile commerce. International Journal of Electronic Commerce, 8(3), 79-102. https://doi.org/10.1080/10864415.2004.11044299

Littlejohn, S. W., \& Foss, K. (2011). Teori komunikasi (Theories of human communication) (Edisi 9). Salemba Humanika.

Mandasari, V., Yuliana, E., \& Telkom, U. (2014). Analisa Proses Keputusan Pembelian Online Pada Toko Buku Gramedia Online Dengan Menggunakan Customer Interface 8C. ( Studi Kasus Pada Www. Gramediaonline. Com Tahun 2014 ) Analysis of Online Purchase Decision Process At Gramedia Online Bookstore Using

Moleong, L. J. (2017). Metodologi Penelitian Kualitatif (Edisi Revisi). In PT. Remaja Rosda Karya.

Morreale, S. P., Spitzberg, B. H., \& Barge, J. K. (2007). Human Communication: Motivation, Knowledge and Skills. Thompson Wadsworth.

Mukhtar. (2013). Metode Praktis dan Penelitian Deskriptif Kualitatif. Jakarta: Referensi (GP 
Jurnal Ilmu Komunikasi UHO : Jurnal Penelitian Kajian Ilmu Komunikasi dan Informasi.

Volume 6, No. 1, Januari 2021, hlm 19-38

Press Group.

Nehls, K., Smith, B. D., \& Schneider, H. A. (2014). Video-conferencing interviews in qualitative research. Enhancing Qualitative and Mixed Methods Research with Technology, January, 140-157. https://doi.org/10.4018/978-1-4666-6493-7.ch006

Prisgunanto, I. (2006). Komunikasi pemasaran: Strategi dan taktik. Ghalia Indonesia.

Putri, S. (2019). Taman Impian Jaya Ancol menjadi Destinasi Favorit Wisatawan. Diakses pada 18 Oktober 2020 dari http://statistik.jakarta.go.id/kunjungan-wisatawan-nusantarahingga-juni-2019-sebesar-1748-juta/

Radhinda, P. A. (2017). Pengaruh customer interface media sosial instagram terhadap tahapan keputusan pembelian konsumen rollover reaction. Universitas Brawijaya.

Rayport, J. F., \& Jaworski, B. J. (2001). E-Commerce. McGraw-Hill.

Robert, K. Y. (2012). Studi Kasus: Desain \& Metode. Rajawali Pers.

Shimp, T. A. (2004). Advertising, Promotion and Supplemental Aspects of Integrated Marketing Communication. Journal of Marketing Communications. https://doi.org/10.1080/1352726042000250498

Verhoef, P. C., Reinartz, W. J., \& Krafft, M. (2010). Customer engagement as a new perspective in customer management. Journal of Service Research. https://doi.org/10.1177/1094670510375461

Yang, T. A., Kim, D. J., Dhalwani, V., \& Vu, T. K. (2008). The $8 \mathrm{C}$ framework as a reference model for collaborative value webs in the context of Web 2.0. Proceedings of the Annual Hawaii International Conference on System Sciences. https://doi.org/10.1109/HICSS.2008.428 